\title{
PENGARUH PENGENDALIAN INTERN TERHADAP AKUNTABILITAS MANAJEMEN KEUANGAN SEKOLAH
}

\author{
Kartikawati \\ Guru SMAN 6 Madiun
}

\begin{abstract}
This study aims to determine controlling effect intern (control environment, risk assessment, control activities, information and communication, and monitoring) on accountability financial management school. This study also uses control variable which is a measure of school and school status. This study uses census. Tests conducted on 98 bendahara primary and secondary schools are elementary, junior high, high school, and $\mathrm{p}$ private SMK Madiun city. Data collection using questionnaire and test analysis using multiple linear regression and statistical analysis diskriptif. Result research shows that the internal control element of evaluation risk, control activities, monitoring, school size and school status have an influence on financial manajement school accountability. Instead the control environment and information and communication has no effect. However jointly affect the internal control of financial management accountability for $85.8 \%$ of the school.
\end{abstract}

Keywords: Internal control, school status, school size, and accountability of financial management of the school

\begin{abstract}
Abstrak: Penelitian ini bertujuan untuk mengetahui pengaruh Pengendalian intern (lingkungan pengendalian, penilaian risiko, kegiatan pengendalian, informasi dan komunikasi, dan pemantauan) terhadap akuntabilitas manajemen keuangan sekolah. Penelitian ini juga menggunakan variabel kontrol yaitu ukuran sekolah dan status sekolah. Penelitian ini menggunakan metode sensus. Pengujian dilakukan terhadap 98 bendahara sekolah dasar dan menengah yaitu SD, SMP, SMA, dan SMK negeri dan swasta di Kota Madiun. Pengumpulan data menggunakan instrumen kuesioner serta analisis pengujian menggunakan regresi linier berganda dan analisis statistik diskriptif. Hasil penelitian menunjukkan bahwa pengendalian intern unsur penilaian risiko, kegiatan pengendalian, pemantauan, ukuran sekolah dan status sekolah mempunyai pengaruh terhadap akuntabilitas manajemen keuangan sekolah. Sebaliknya lingkungan pengendalian dan informasi dan komunikasi tidak berpengaruh. Namun secara bersama-sama pengendalian intern berpengaruh terhadap akuntabilitas manajemen keuangan sekolah sebesar $85,8 \%$.
\end{abstract}

Kata Kunci: Pengendalian intern, status sekolah, ukuran sekolah, dan akuntabilitas manajemen keuangan sekolah

\section{PENDAHULUAN}

Undang-undang Nomor 20 Tahun 2003 tentang Sistem Pendidikan Nasional, menyebutkan bahwa "masyarakat berhak berperan serta dalam perencanaan, pelaksanaan, pengawasan, dan evaluasi program pendidikan" serta "masyarakat berkewajiban memberikan dukungan sumber daya dalam penyelenggaraan pendidikan". Namun dalam rangka mewujudkan cita-cita pendidikan nasional, sampai saat ini pemerintah dihadapkan dengan berbagai permasalahan, seperti tingkat kualitas pendidik yang belum memenuhi standar mutu, sarana prasarana sekolah yang masih kurang memadai, serta terbatasnya anggaran pendidikan yang 
disediakan oleh pemerintah (Anggraini, 2013).

Menurut Wijaya (2009) dalam rangka wajib belajar 9 tahun, pemerintah telah berupaya mengalokasikan sebagian besar dananya ke salah satu program di bidang pendidikan yakni Program Bantuan Operasional Sekolah (BOS). Program ini memberikan dukungan kepada sekolah dalam menerapkan konsep MBS (Manajemen Berbasis Sekolah). Permendiknas No. 19 tahun 2007 tentang Standar Pengelolaan Pendidikan oleh Satuan Pendidikan Dasar dan Menengah mengamanatkan bahwa pengelolaan dana baik dari pemerintah maupun dari masyarakat harus dilandasi semangat akuntabilitas dan transparansi.

Dalam implementasi MBS, manajemen keuangan sekolah harus dijalankan dengan baik dan teliti mulai dari tahap penyusunan anggaran, penggunaan, sampai pengawasan dan pertanggungjawaban sesuai dengan ketentuan yang berlaku agar semua dana sekolah benar-benar dimanfaatkan secara efisien, efektif, tidak ada kebocoran, serta bebas penyakit korupsi, kolusi, dan nepotisme.

Wilopo (2006) menyatakan bahwa kecurangan akuntansi telah berkembang di berbagai negara termasuk di Indonesia. Di dunia pendidikan ada beberapa kasus penyimpangan dan penyalahgunaan keuangan sekolah, mulai dari pengadaan perlengkapan sekolah, penyalahgunaan BOS, serta dana alokasi khusus (DAK) pendidikan.

Jaringan Kerja Anti Korupsi Jawa Timur menemukan indikasi penyelewengan pengelolaan dana keuangan sekolah di Surabaya, Malang, dan Jember (http://beritapendidikan.co.id).

Demikian juga, di Kota Madiun terbukti tahun 2014 telah ada dua Kepala SMA Negeri divonis bersalah oleh Pengadilan Tipikor Jawa Timur (Jawa Pos, 2014).

Dalam pernyataan KPK bersama BPKP, Kemendikbud, Kemenag, Kemenkue, dan Kemendagri berhasil memetakan pola korupsi yang ada di sektor pendidikan sebagai $4 \mathrm{~L}$, yaitu lemahnya sistem administrasi data karena tidak andal dan tidak tepat sasaran, lemahnya pengendalian internal, lemahnya pengawasan, dan lemahnya kontrol sosial dari masyarakat karena tidak tahu mengenai aturan dan mekanisme. (http:// mediaindonesia.com).

Menurut Abbot et al. dalam Wilopo (2006) menyatakan bahwa untuk mengurangi kecenderungan kecurangan dalam organisasi perlu diterapkan pengendalian intern yang efektif. Tujuan pengendalian intern adalah tercapainya efektifitas dan efisiensi pencapaian tujuan penyelenggaraan pemerintahan negara, keandalan laporan keuangan, pengamanan aset negara, dan ketaatan terhadap peraturan perundang-undangan (Peraturan Pemerintah No. 60 Tahun 2008).

\section{Landasan Teori}

\section{Pengertian Sistem Pengendalian Intern}

Moeller (2007), Teketel dan Berbanu (2009), Martani dan Zaelani (2011), Sari (2013), dan Fadilah (2011) mendefinisikan pengendalian intern sebagai sebuah proses yang dirancang untuk memberikan keyakinan memadai tentang pencapaian tujuan dalam efektivitas dan efisiensi operasi, keandalan pelaporan keuangan, dan kepatuhan terhadap hukum dan peraturan yang berlaku.

Pedoman Teknis Penyelenggaraan SPIP di Lingkungan Kemendikbud (2012: 3) dan Peraturan Pemerintah Nomor 60 Tahun 2008 bahwa pengendalian intern adalah proses yang integral pada kegiatan dan tindakan yang dilakukan secara terusmenerus oleh pimpinan dan seluruh pegawai untuk memberikan keyakinan memadai atas tercapainya tujuan organisasi, melalui kegiatan yang efektif dan efisien, keandalan pelaporan keuangan, pengamanan aset negara, serta ketaatan terhadap peraturan perundang-undangan yang diselenggarakan secara menyeluruh di lingkungan pemerintah pusat dan pemerintah daerah. Lebih lengkapnya menurut Kresiadanti (2012) bahwa 
pengendalian intern adalah suatu proses yang ada pada aktivitas operasi organisasi dan merupakan bagian integral dari proses manajemen seperti perencanaan, pelaksanaan, dan pengendalian. Pengendalian intern merupakan bagian integral dari proses manajemen, karena konsep sebuah pengendalian intern adalah proses (processes), dilaksanakan oleh manusia (effected to people) dan tujuan yang diharapkan (objectives).

Dari uraian di atas dapat disimpulkan bahwa sistem pengendalian intern adalah proses perencanaan dan penerapan lima unsur (lingkungan pengendalian, penilaian risiko, kegiatan pengendalian, informasi dan komunikasi, serta pemantauan) secara integral pada kegiatan dan tindakan yang dilakukan secara terus-menerus oleh pimpinan/kepala sekolah atau manajemen dan seluruh pegawai untuk memberikan keyakinan memadai atas tercapainya tujuan organisasi, melalui kegiatan yang efektif dan efisien, keandalan pelaporan keuangan, pengamanan aset negara, serta ketaatan terhadap peraturan perundang-undangan yang diselenggarakan secara menyeluruh di lingkungan pemerintah pusat, pemerintah daerah, dan unit pengelola pendidikan (sekolah).

\section{Tujuan Pengendalian Intern}

Menurut Teketel dan Berhanu (2009) bahwa tujuan pengendalian intern dirancang untuk memberikan jaminan bahwa tujuan organisasi akan dapat dicapai melalui efisiensi dan efektivitas operasi, penyajian laporan keuangan yang dapat dipercaya, dan ketaatan terhadap undang-undang dan aturan yang berlaku. Tujuan SPIP dalam Pedoman Teknis Penyelenggaraan SPIP di Lingkungan Kemendikbud (2012) dan Peraturan Pemerintah No. 60 tahun 2008 adalah memberikan keyakinan memadai atas tercapainya efektifitas dan efisiensi pencapaian tujuan penyelenggaraan pemerintahan negara, keandalan laporan keuangan, pengamanan aset negara, dan ketaatan terhadap peraturan perundang-undangan.

\section{Unsur-unsur Pengendalian Intern}

Moeller (2007); Teketel dan Berbanu (2009), Martani dan Zaelani (2011), Sari (2013), Fadilah (2011), Kresiadanti (2012) maupun PP Nomor 60 Tahun 2008 dan Kemendikbud (2012) menyatakan ada lima unsur sistem pengendalian intern yakni: (a) Lingkungan pengendalian, (b) Penilaian risiko, (c) Kegiatan pengendalian, (d) Informasi dan komunikasi, (e) Pemantauan. Secara lebih detail kelima unsur pengendalian tersebut dibahas sebagai berikut.

a. Lingkungan pengendalian

Pratolo (2007) menuliskan bahwa lingkungan pengendalian meliputi integritas dan nilai etika, komitmen terhadap kompetensi, partisipasi dewan pengawas, filosofi manajemen dan gaya operasi, struktur organisasi, pelimpahan wewenang dan tanggung jawab serta kebijaksanaan dan praktik sumber daya manusia. Mustafa (2004) menyatakan bahwa lingkungan pengendalian adalah tindakan, kebijakan, dan prosedur yang menggambarkan seluruh sikap manajemen puncak, dewan komisaris, dan pemilik entitas tentang pentingnya pengendalian dalam suatu entitas. Dapat disimpulkan bahwa lingkungan pengendalian menjadi dasar bagi sistem pengendalian internal yang memadai bagi organisasi melalui kepemimpinan, nilai bersama, dan budaya yang menekankan akuntabilitas untuk pengendalian.

\section{b. Penilaian risiko}

Pengendalian intern harus memberikan penilaian atas risiko yang dihadapi unit organisasi baik dari luar maupun dari dalam (PP Nomor 60 Tahun 2008 dan Kemendikbud, 2012). Menurut Teketel dan Berhanu (2009) selain penilaian risiko yang berasal dari dalam maupun dari luar, persyaratan penilaian risiko adalah identifikasi tujuannya dengan jelas.

Menurut Istiningrum (2011), tiga unsur yang harus selalu dipenuhi oleh instansi 
pendidikan ketika akan mengidentifikasi risiko yaitu (1) kemungkinan kejadian atau peristiwa, (2) dampak atau konsekuensikonsekuensi (jika terjadi, risiko akan membawa akibat atau konsekuensi) dan (3) kemungkinan kejadian (risiko masih berupa kemungkinan atau diukur dalam bentuk probabilitas). Ketiga unsur tersebut harus selalu dipenuhi oleh instansi pendidikan ketika akan mengidentifikasi risiko.

c. Kegiatan pengendalian

Kegiatan pengendalian merupakan bagian yang integral dari perencanaan, pelaksanaan, pengevaluasian dan akuntabilitas dari instansi pemerintahan terhadap pengelolaan sumber daya negara dan pencapaian tujuantujuan dengan efektif. Kegiatan pengendalian membantu memastikan bahwa arahan pimpinan instansi pemerintah dilaksanakan. Kegiatan pengendalian harus efisien dan efektif dalam pencapaian tujuan organisasi (PP Nomor 60 Tahun 2008 dan Kemendikbud, 2012). Teketel dan Berhanu (2009) menyatakan bahwa kegiatan pengendalian merupakan kebijakan dan prosedur yang membantu memastikan bahwa arahan manajemen dilaksanakan dan memastikan bahwa tindakan perlu diambil untuk mengatasi risiko dalam pencapaian tujuan organisasi, serta elemen kegiatan pengendalian meliputi persetujuan, otorisasi, dan verifikasi.

\section{d. Informasi dan komunikasi}

Informasi harus dicatat dan dilaporkan kepada pimpinan Instansi Pemerintah dan pihak lain yang ditentukan. Teketel dan Berhanu (2009) menyatakan bahwa kelancaran arus informasi dan komunikasi internal menjadi salah satu mekanisme untuk memastikan pengendalian intern yang efektif, informasi harus diidentifikasi, ditangkap dan dikomunikasikan yang memungkinkan orang untuk melaksanakan tanggungjawabnya dan diharapkan karyawan ikut berpartisipasi. Zhumei, Hongwei dan Yanli (2013) mengungkapkan bahwa keterbukaan informasi dan komunikasi menunjukkan bahwa efektivitas pengendalian intern memiliki prediksi yang semakin baik.

\section{e. Pemantauan}

Pemantauan harus dapat menilai kualitas kinerja dari waktu ke waktu dan memastikan bahwa rekomendasi hasil audit dan review lainnya dapat segera ditindaklanjuti (PP Nomor 60 Tahun 2008 dan Kemendikbud, 2012). Teketel dan Berhanu (2009) menyatakan bahwa kualitas pengendalian internal dilakukan secara terusmenerus dimana pemantauan dan evaluasi merupakan suatu kesatuan sistem yang tidak bisa dipisahkan dari empat unsur yang lain. Kegiatan ini meliputi berbagai kegiatan pengelolaan dan pengawasan serta mengevaluasi pelaksanaannya agar pengendalian internal dapat berjalan secara efektif.

\section{Manajemen Keuangan Sekolah}

Sesuai berkembangnya otonomi daerah, di dalam lingkup pendidikan formal, mulai muncul konsep Manajemen Berbasis Sekolah (MBS) yang menjadikan pengelolaan pendidikan lebih terarah dan terkoordinasi dengan baik dari segi penyelenggaraan, pendanaan, pengembangan, dan pengawasan.

Mulyasa (2003:11) menyatakan bahwa manajemen berbasis sekolah (MBS) atau school based manajemen (SBM) merupakan salah satu pemikiran ke arah pengelolaan pendidikan yang memberi keleluasaan kepada sekolah untuk mengatur dan melaksanakan berbagai kebijakan secara luas. Manajemen keuangan merupakan salah satu substansi manajamen sekolah yang akan turut menentukan berjalannya kegiatan pendidikan di sekolah. Substansi manajemen pendidikan pada umumnya adalah kegiatan manajemen keuangan yang dilakukan melalui proses perencanaan, pengorganisasian, pengarahan, pengawasan dan pengendalian, serta pelaporan.

\section{Tujuan Manajemen Keuangan Sekolah}

Menurut Mulyasa (2003) melalui kegiatan manajemen keuangan maka kebutuhan pendanaan kegiatan sekolah dapat direncanakan, diupayakan pengadaannya, dibukukan secara transparan, dan digunakan 
untuk membiayai pelaksanaan program sekolah secara efektif dan efisien. Untuk itu tujuan manajemen keuangan adalah: (a) meningkatkan efektivitas dan efisiensi penggunaan keuangan sekolah, (b) meningkatkan akuntabilitas dan transparansi keuangan sekolah, (c) meminimalkan penyalahgunaan anggaran sekolah. Untuk mencapai tujuan tersebut, maka dibutuhkan kreativitas kepala sekolah dalam menggali sumber-sumber dana, menempatkan bendaharawan yang menguasai dalam pembukuan dan pertanggungjawaban keuangan serta memanfaatkannya secara benar sesuai peraturan perundangan yang berlaku.

\section{Prinsip-Prinsip Manajemen Keuangan Sekolah}

Menurut Undang-undang Nomor 20 Tahun 2003 pasal 48 dinyatakan bahwa prinsip-prinsip dalam pengelolaan dana pendidikan oleh pemerintah, pemerintah daerah, penyelenggara dan satuan pendidikan yang didirikan oleh masyarakat terdiri atas prinsip-prinsip umum dan prinsip-prinsip khusus. Prinsip-prinsip umum manajemen keuangan sekolah yaitu keadilan, efisiensi, transparansi dan akuntabilitas. Prinsipprinsip khusus manajemen keuangan sekolah meliputi efektif, kecukupan, dan keberlanjutan.

\section{Peran dan Fungsi Manajeman Keuangan}

\section{Sekolah}

Peran dan fungsi manajemen keuangan sekolah adalah menyediakan berbagai informasi kuantitatif, terutama yang bersifat keuangan, agar berguna dalam pengambilan keputusan ekonomi pada suatu entitas pendidikan (Bastian, 2007). Berbagai informasi keuangan tersebut dapat digunakan oleh stakeholders sekolah yaitu kepala sekolah, guru dan karyawan, kreditur, orang tua siswa, pemasok, pemerintah dan masyarakat.

Bafadal (2004) menyatakan bahwa fungsi dari manajemen keuangan sekolah meliputi kegiatan-kegiatan: (a) perencanaan anggaran tahunan, (b) pengadaan anggaran, (c) pendistribusian anggaran, (d) pelaksanaan anggaran, (e) pembukuan keuangan, dan (f) pengawasan dan pertanggungjawaban keuangan.

\section{Akuntabilitas Manajemen Keuangan Sekolah}

1. Pengertian Akuntabilitas

Akuntabilitas secara harfiah, dalam bahasa Inggris disebut accountability, yang diartikan sebagai "keadaan untuk dipertanggungjawabkan". Dalam dunia pekerjaan istilah akuntabilitas adalah kewajiban untuk menyajikan rekening dan menjawab dalam pelaksanaan tanggung jawab kepada mereka yang telah dipercayakan tanggung jawab tersebut.

Fenomena dalam perkembangan sektor publik dewasa ini adalah semakin menguatnya tuntutan pelaksanaan akuntabilitas publik oleh organisasi sektor publik (seperti: pemerintah pusat dan daerah, unit-unit kerja pemerintah, departemen dan lembaga-lembaga negara). Akuntabilitas dapat diartikan sebagai bentuk kewajiban mempertanggungjawabkan keberhasilan atau kegagalan pelaksanaan misi organisasi dalam mencapai tujuan dan sasaran yang telah ditetapkan sebelumnya, melalui suatu media pertanggungjawaban yang dilaksanakan secara periodik (Stanbury dalam Mardiasmo, 2006).

Slamet (2006:6) menyatakan bahwa untuk mewujudkan akuntabilitas yang tinggi dalam pelaksanaan MBS harus bertumpu pada kemampuan dan kemauan sekolah. Sekolah mengetahui sumber daya yang dimiliki, sehingga dapat digerakkan untuk mewujudkan dan meningkatkan akuntabilitas. Sekolah dapat melibatkan stakeholders untuk menyusun dan memperbaharui sistem yang dianggap tidak dapat menjamin terwujudnya akuntabilitas di sekolah.

\section{Indikator Keberhasilan Akuntabilitas}

Muhammad (2004:43) menyatakan bahwa berhasil tidaknya akuntabilitas dalam MBS dapat dilihat dari: (a) Pertanggung jawaban pengelolaan keuangan. (b) Penilaian kinerja keuangan. (c) Sistem informasi yang 
handal. (d) Akuntabilitas kinerja keuangan dinilai secara obyektif dan independen. Zamroni (2008:12) menyatakan bahwa akuntabilitas hanya dapat terjadi jika ada partisipasi dari stakeholders sekolah. Semakin kecil partisipasi stakeholders dalam penyelenggaraan manajemen sekolah, maka akan semakin rendah pula akuntabilitas sekolah.

\section{Kerangka Berpikir}

Berdasarkan permasalahan dalam penelitian ini, maka dapat dibuat kerangka berfikir sebagai berikut.

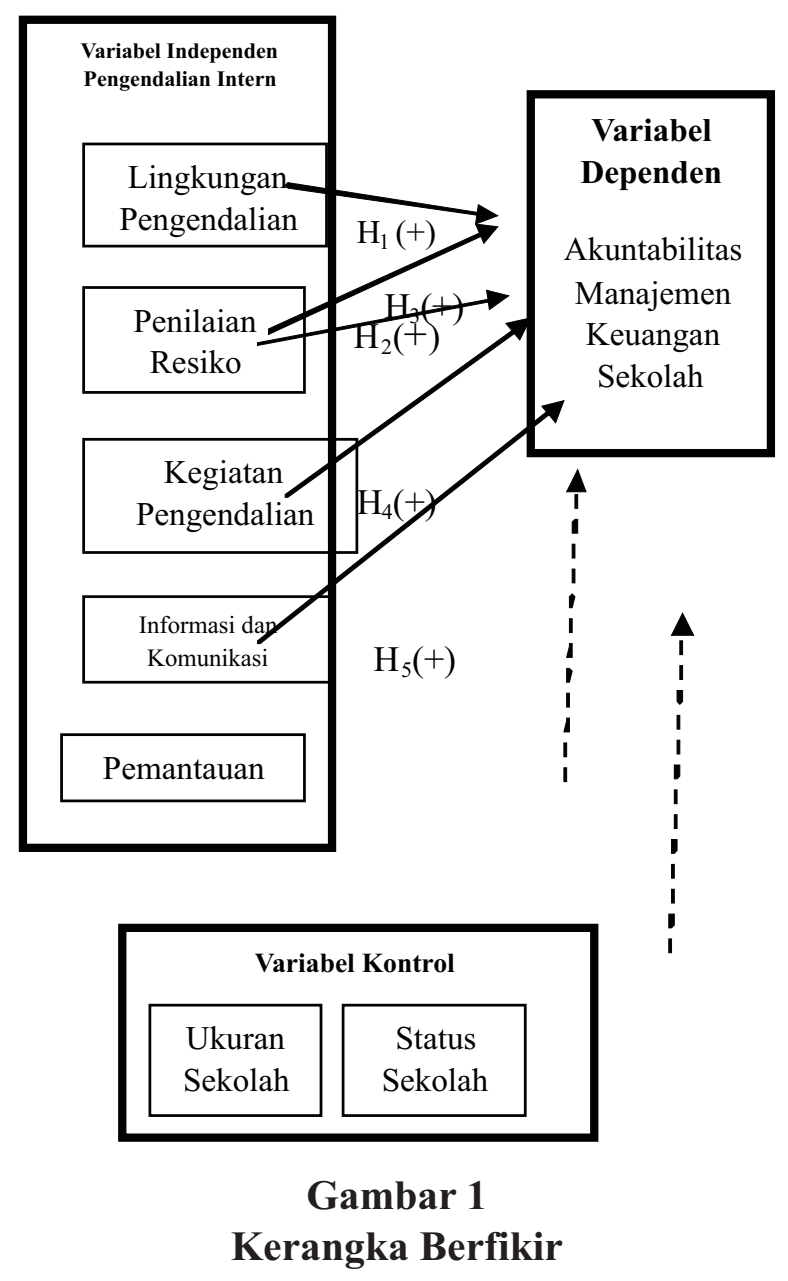

Keterangan:

$\rightarrow$ : mempengaruhi langsung

$\rightarrow$ : mempengaruhi tidak langsung

\section{METODE}

Penelitian ini menggunakan desain deskriptif kuantitatif analitik yang berfungsi untuk mengetahui besarnya pengaruh antara variabel-variabel dalam penelitian.

\section{Populasi dan Sampel}

Metode pengambilan sampel dalam penelitian ini adalah dengan metode sampling jenuh atau lebih dikenal dengan istilah sensus. Populasi yang digunakan adalah semua sekolah di Kota Madiun, demikian juga sampelnya adalah sekolah yang ada di Kota Madiun sebanyak 152 sekolah yang terdiri dari SD sebanyak 83 lembaga, SMP sebanyak 24 lembaga, dan SMA/SMK sebanyak 45 lembaga.

Model yang digunakan untuk menguji hipotesis dalam penelitian ini adalah model regresi berganda (multiple regression).

\section{Hasil dan Pembahasan}

\section{Karakteristik Responden}

Dari hasil penelitian yang telah dilakukan, diketahui identitas responden dikategorikan menjadi 4 yaitu berdasarkan: jenis kelamin, umur, tingkat pendidikan, dan masa kerja.

\section{Deskripsi Variabel Penelitian}

Deskriptif statistik secara umum dapat menggambarkan nilai minimum, maximum, mean, dan standar deviasi telah diringkas seperti pada tabel berikut:

Tabel 1

\section{Deskripsi Variabel Penelitian}

\begin{tabular}{ccccc}
\hline Variabel & Minimum & Maximum & Mean & $\begin{array}{c}\text { Std. } \\
\text { Deviation }\end{array}$ \\
\hline LP & 19.00 & 36.00 & 27.78 & 4.07 \\
PR & 6.00 & 17.00 & 12.55 & 2.41 \\
KP & 6.00 & 23.00 & 15.63 & 3.20 \\
IK & 6.00 & 19.00 & 12.07 & 2.96 \\
PM & 4.00 & 18.00 & 11.97 & 3.03 \\
US & 18.00 & 1589.00 & 272.47 & 26.28 \\
SS & 0 & 1 & 0.74 & .438 \\
AMKS & 27.00 & 48.00 & 39.58 & 4.74 \\
\hline
\end{tabular}

Catatan: LP (lingkungan pengendalian); PR (penilaian risiko); KP (kegiatan pengendalian); IK (informasi dan komunikasi); PM (pemantauan); US (ukuran sekolah); dan SS (status sekolah); AMKS (Akuntabilitas Manajemen Keuangan Sekolah) 
Variabel US sebagai variabel kontrol, maka variabel ini dapat dikendalikan/konstan sehingga hubungan variabel independen (variabel bebas) terhadap variabel dependen (variabel terikat) tidak dipengaruhi oleh faktor luar yang tidak diteliti.

Sedangkan nilai variabel SS (status sekolah) dapat dilihat pada tabel di bawah.

Tabel 2

Distribusi Status Sekolah

\begin{tabular}{ccccc}
\hline & \multicolumn{4}{c}{ Status Sekolah } \\
\cline { 2 - 5 } Jenjang & \multicolumn{2}{c}{ Negeri } & \multicolumn{3}{c}{ Swasta } \\
\cline { 2 - 5 } Sekolah & Jumlah & $\%$ & Jumlah & $\%$ \\
\hline SD & 48 & $49 \%$ & 10 & $10 \%$ \\
SMP & 14 & $14 \%$ & 4 & $4 \%$ \\
SMA & 6 & $6 \%$ & 3 & $3 \%$ \\
SMK & 5 & $5 \%$ & 8 & $8 \%$ \\
\hline Jumlah & 73 & $74 \%$ & 25 & $26 \%$ \\
\hline Total & \multicolumn{5}{c}{$98(100 \%)$} \\
\hline
\end{tabular}

Sumber: data sekunder diolah, tahun 2014

\section{Hasil Uji Instrumen}

a. Hasil Uji Validitas

Dalam pengujian dinyatakan valid bila memiliki $r$ hitung lebih tinggi daripada $r$ tabel pada taraf signifikansi $5 \%$ yaitu 0,361 .

1) Variabel LP (Lingkungan Pengendalian)

Tabel 3

Hasil Uji Validitas Variabel LP (Lingkungan Pengendalian)

\begin{tabular}{cccc}
\hline $\begin{array}{c}\text { No. } \\
\text { Pernyataan }\end{array}$ & $\begin{array}{c}\text { Koefisien } \\
\text { Korelasi } \\
\text { Pearson }\end{array}$ & $\begin{array}{c}\text { Taraf } \\
\text { sign 5\% }\end{array}$ & Ket \\
\hline 1 & 0,681 & 0,361 & valid \\
2 & 0,492 & 0,361 & valid \\
3 & 0,663 & 0,361 & valid \\
4 & 0,644 & 0,361 & valid \\
5 & 0,58 & 0,361 & valid \\
6 & 0,721 & 0,361 & valid \\
7 & 0,667 & 0,361 & valid \\
8 & 0,756 & 0,361 & valid \\
9 & 0,681 & 0,361 & valid \\
\hline
\end{tabular}

Sumber: data primer diolah, tahun 2014
2) Variabel PR (Penilaian Risiko)

Tabel 4

Hasil Uji Validitas Variabel PR (Penilaian Risiko)

\begin{tabular}{clcl}
\hline $\begin{array}{c}\text { No. } \\
\text { Pernyataan }\end{array}$ & $\begin{array}{c}\text { Koefisien } \\
\text { Korelasi } \\
\text { Pearson }\end{array}$ & $\begin{array}{c}\text { Taraf } \\
\text { sign } \\
5 \%\end{array}$ & Ket \\
\hline 1 & 0,89 & 0,361 & valid \\
2 & 0,74 & 0,361 & valid \\
3 & 0,846 & 0,361 & valid \\
4 & 0,745 & 0,361 & valid \\
\hline
\end{tabular}

Sumber: data primer diolah, tahun 2014

3) Variabel KP (Kegiatan Pengendalian)

Tabel 5

Hasil Uji Validitas Variabel KP (Kegiatan Pengendalian)

\begin{tabular}{cccc}
\hline $\begin{array}{c}\text { No. } \\
\text { Pernyataan }\end{array}$ & $\begin{array}{c}\text { Koefisien } \\
\text { Korelasi } \\
\text { Pearson }\end{array}$ & $\begin{array}{c}\text { Taraf } \\
\text { sign 5\% }\end{array}$ & Ket \\
\hline 1 & 0,808 & 0,361 & valid \\
2 & 0,740 & 0,361 & valid \\
3 & 0,779 & 0,361 & valid \\
4 & 0,744 & 0,361 & valid \\
5 & 0,707 & 0,361 & valid \\
\hline
\end{tabular}

Sumber: data primer diolah, tahun 2014

4) Variabel IK (Informasi dan Komunikasi)

Tabel 6

Hasil Uji Validitas Variabel IK (Informasi dan Komunikasi)

\begin{tabular}{clcl}
\hline $\begin{array}{c}\text { No. } \\
\text { Pernyataan }\end{array}$ & $\begin{array}{c}\text { Koefisien } \\
\text { Korelasi } \\
\text { Pearson }\end{array}$ & $\begin{array}{c}\text { Taraf } \\
\text { sign } \\
5 \%\end{array}$ & Ket \\
\hline 1 & 0,845 & 0,361 & valid \\
2 & 0,848 & 0,361 & valid \\
3 & 0,799 & 0,361 & valid \\
4 & 0,776 & 0,361 & valid \\
\hline
\end{tabular}

Sumber: data primer diolah, tahun 2014 
5) Variabel PM (Pemantauan)

Tabel 7

Hasil Uji Validitas Variabel PM (Pemantauan)

\begin{tabular}{cccc}
\hline $\begin{array}{c}\text { No. } \\
\text { Pernyataan }\end{array}$ & $\begin{array}{c}\text { Koefisien } \\
\text { Korelasi } \\
\text { Pearson }\end{array}$ & $\begin{array}{c}\text { Taraf } \\
\text { sign 5\% }\end{array}$ & Ket \\
\hline 1 & 0,854 & 0,361 & valid \\
2 & 0,878 & 0,361 & valid \\
3 & 0,790 & 0,361 & valid \\
4 & 0,760 & 0,361 & valid \\
\hline
\end{tabular}

Sumber: data primer diolah, tahun 2014

6) Variabel akuntabilitas manajemen keuangan sekolah (AMKS)

\section{Tabel 8}

Hasil Uji Validitas Variabel AMKS (Akuntabilitas Manajemen Keuangan Sekolah)

\begin{tabular}{clcc}
\hline $\begin{array}{c}\text { No. } \\
\text { Pernyatan }\end{array}$ & $\begin{array}{c}\text { Koefisien } \\
\text { Korelasi } \\
\text { Pearson }\end{array}$ & $\begin{array}{c}\text { Taraf } \\
\text { sign 5\%) }\end{array}$ & Ket \\
\hline 1 & 0,859 & 0,361 & valid \\
2 & 0,855 & 0,361 & valid \\
3 & 0,588 & 0,361 & valid \\
4 & 0,661 & 0,361 & valid \\
5 & 0,622 & 0,361 & valid \\
6 & 0,717 & 0,361 & valid \\
7 & 0,666 & 0,361 & valid \\
8 & 0,616 & 0,361 & valid \\
9 & 0,665 & 0,361 & valid \\
10 & 0,671 & 0,361 & valid \\
11 & 0,517 & 0,361 & valid \\
12 & 0,606 & 0,361 & valid \\
13 & 0,703 & 0,361 & valid \\
\hline
\end{tabular}

Sumber: data primer diolah, tahun 2014

\section{b. Hasil Uji Reliabilitas}

Hasil uji reliabilitas menunjukkan besarnya koefisien cronbach's alpha adalah sebesar 0,691, dengan menggunakan acuan cronbach's alpha sebesar 0,60 (Nunnally 1967 dalam Ghozali 2006:44) maka dapat disimpulkan bahwa keenam variabel memiliki reliabilitas yang memadai karena sudah melebihi batas 0,60 .
Tabel 9

Hasil Uji Reliabilitas Variabel

\begin{tabular}{lll}
\hline \multicolumn{1}{c}{ Variabel } & $\begin{array}{c}\text { Cronbach's } \\
\text { Alpha }\end{array}$ & Keterangan \\
\hline AMKS & 0,900 & Reliabel \\
LP & 0,832 & Reliabel \\
PR & 0,821 & Reliabel \\
KP & 0,812 & Reliabel \\
IK & 0,833 & Reliabel \\
PM & 0,839 & Reliabel \\
\hline
\end{tabular}

Sumber: data primer diolah, tahun 2014

c. Hasil Uji Asumsi Klasik

1) Hasil Uji Normalitas

Pengujian normalitas menggunakan alat uji statistik non-parametrik Kolmogorov Smirnov Test (K-S Test).

Tabel 10

\section{Hasil Uji Normalitas Residual Data}

One-Sample Kolmogorov-Smirnov Test

\begin{tabular}{|c|c|c|}
\hline & & $\begin{array}{l}\text { Unstandardized } \\
\text { Residual }\end{array}$ \\
\hline $\mathrm{N}$ & & 98 \\
\hline \multirow[t]{2}{*}{ Normal Parameters } & $\begin{array}{l}\text { Mean } \\
\text { Std. }\end{array}$ & 0 \\
\hline & Deviation & 178.451 \\
\hline \multicolumn{3}{|l|}{ Most Extreme } \\
\hline \multirow[t]{3}{*}{ Differences } & Absolute & 0.084 \\
\hline & Positive & 0.048 \\
\hline & Negative & -0.084 \\
\hline Kolmogorov-Smirnov Z & & 0.829 \\
\hline Asymp. Sig. (2-tailed) & & 0.497 \\
\hline
\end{tabular}

2) Hasil Uji Multikolinearitas

Hasil uji multikolinearitas dalam penelitian ini, dimana nilai Tolerance menunjukkan bahwa tidak ada variabel independen yang memiliki nilai kurang dari 0,10 , demikian juga dengan nilai VIF yang menunjukkan bahwa tidak ada satu variabel independen yang memiliki nilai VIF lebih dari 10. Dengan demikian dapat disimpulkan bahwa data hasil penelitian ini tidak terjadi 
multikolinieritas pada model regresi linear berganda, yang berarti asumsi multikolinieritas ditolak dan model regresi memenuhi asumsi klasik dan selanjutnya dapat dilakukan uji heteroskedastisitas.

\section{Tabel 11}

Hasil Uji Multikolinieritas

\begin{tabular}{lccccccc}
\hline Variabel & B & Error & Beta & $\mathrm{t}$ & Sig. & Tolerance & VIF \\
\hline (Constant) & 19.16 & 2.047 & & 9.36 & 0 & & \\
LP & 0.049 & 0.081 & 0.04 & 0.6 & 0.55 & 0.327 & 3.06 \\
PR & 0.424 & 0.09 & 0.22 & 4.73 & 0 & 0.759 & 1.32 \\
KP & 0.311 & 0.103 & 0.21 & 3.03 & 0 & 0.327 & 3.06 \\
IK & 0.144 & 0.091 & 0.09 & 1.59 & 0.12 & 0.49 & 2.04 \\
PM & 0.207 & 0.085 & 0.13 & 2.44 & 0.02 & 0.537 & 1.86 \\
US & 0.009 & 0.001 & 0.48 & 7.13 & 0 & 0.35 & 2.86 \\
SS & 1.329 & 0.525 & 0.12 & 2.53 & 0.01 & 0.668 & 1.5 \\
\hline
\end{tabular}

Sumber: hasil pengolahan data dengan SPSS 19.00

\section{3) Hasil Uji Heteroskedastisitas}

Hasil uji heterokedastisitas menunjukkan nilai probabilitas (sig) dalam tiap model regresi yang digunakan dalam penelitian ini lebih besar dari $5 \%$.

\section{Tabel 12}

\section{Hasil Uji Heteroskedastisitas}

\begin{tabular}{|c|c|c|c|}
\hline Variabel & $\mathrm{t}$ & Siq & Keterangan \\
\hline (Constant) & 1.952 & .054 & $\begin{array}{c}\text { Tidak Terjadi } \\
\text { Heteroskedastisitas }\end{array}$ \\
\hline LP & 1.899 & .061 & $\begin{array}{c}\text { Tidak Terjadi } \\
\text { Heteroskedastisitas }\end{array}$ \\
\hline PR & -1.120 & .064 & $\begin{array}{c}\text { Tidak Terjadi } \\
\text { Heteroskedastisitas }\end{array}$ \\
\hline $\mathrm{KP}$ & -1.112 & .065 & $\begin{array}{c}\text { Tidak Terjadi } \\
\text { Heteroskedastisitas }\end{array}$ \\
\hline IK & 1.221 & .225 & $\begin{array}{c}\text { Tidak Terjadi } \\
\text { Heteroskedastisitas }\end{array}$ \\
\hline $\mathrm{PM}$ & -.784 & .435 & $\begin{array}{c}\text { Tidak Terjadi } \\
\text { Heteroskedastisitas }\end{array}$ \\
\hline US & 1.348 & .077 & $\begin{array}{c}\text { Tidak Terjadi } \\
\text { Heteroskedastisitas }\end{array}$ \\
\hline SS & 1.033 & .305 & $\begin{array}{c}\text { Tidak Terjadi } \\
\text { Heteroskedastisitas }\end{array}$ \\
\hline
\end{tabular}

Sumber: hasil pengolahan data dengan SPSS 19.00

\section{4) Hasil Uji Autokorelasi}

Uji autokorelasi dilakukan dengan menggunakan uji Durbin-Watson (DW test) yaitu dengan membandingkan nilai Durbin Watson hitung dengan nilai DW tabel dengan hasil sebagai berikut:
Tabel 13

Uji Durbin-Watson Test

\begin{tabular}{lc}
\hline \multicolumn{1}{c}{ KETERANGAN } & HASIL UJI \\
\hline $\mathrm{R}$ & 0,926 \\
$\mathrm{R}$ Square & 0,858 \\
Adjusted R Square & 0,847 \\
Std. Error of the Estimate & 185.262 \\
Durbin-Watson & 1.883 \\
\hline
\end{tabular}

Sumber: data primer diolah, 2014

Hasil uji Durbin-Watson menunjukkan bahwa nilai dl (batas bawah) $=1,512$ dan $\mathrm{du}=$ 1,827 dengan tingkat signifikansi 0,05 . Oleh karena itu nilai $\mathrm{DW}_{\text {hitung }}$ lebih besar dari batas atas $(\mathrm{du})(1,883>1,827)$ dan kurang dari $4-\mathrm{du}$ $(4-1,883=2,117<1,883)$. Dari hasil tersebut, kesimpulan yang dapat diambil adalah tidak terdapat gejala autokorelasi baik positif maupun negatif, maka syarat tidak terjadinya autokorelasi dipenuhi.

\section{Hasil Pengujian Hipotesis}

Pengujian hipotesis dilakukan melalui model regresi berganda. Uji koefisien regresi dengan uji t ini digunakan untuk mengetahui apakah variabel independen (pengendalian intern) berpengaruh secara signifikan ter-hadap variabel dependen (akuntabilitas manajemen keuangan sekolah) serta variabel kontrol.

Tabel 14

Hasil Uji Hipotesa dengan Uji t, F, dan R

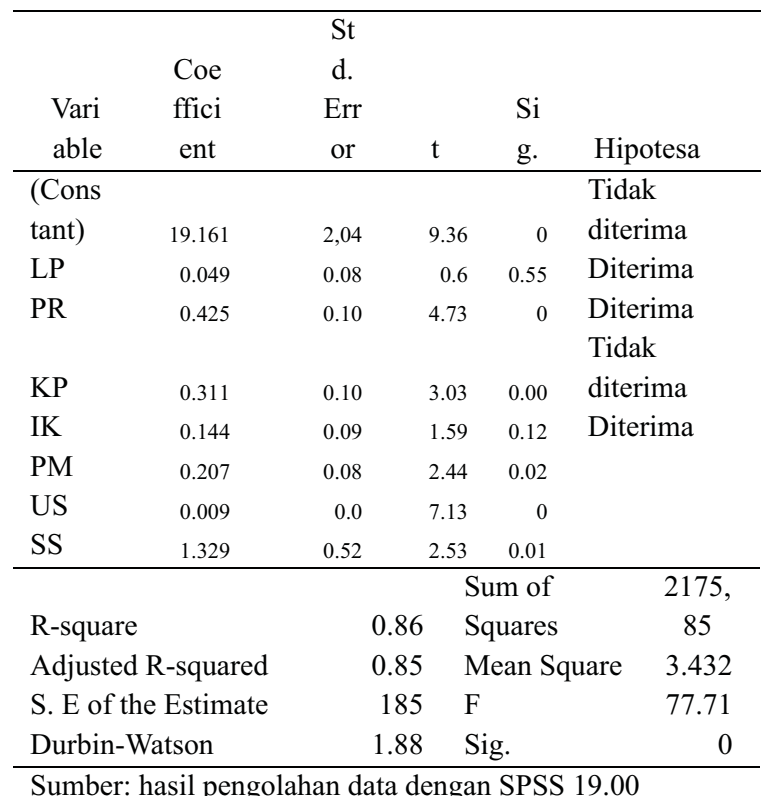

Sumber: hasil pengolahan data dengan SPSS 19.00 
Dari tabel di atas, maka dapat dituliskan persamaan regresinya sebagai berikut: $\mathrm{AMKS}=19,161+0,049 \mathrm{LP}+0,424 \mathrm{PR}+$ $0,311 \mathrm{KP}+0,144 \mathrm{IK}+0,207 \mathrm{PM}+0,009 \mathrm{US}+$ $1,329 \mathrm{SS}$.

Hasil uji $F$ tampak pada tabel menunjukkan bahwa nilai $p$ sebesar 0,000 dan 0,000 $<0,05$, maka $\mathrm{H}_{0}$ ditolak. Berdasarkan hasil uji tersebut dapat diartikan bahwa pengendalian intern berpengaruh terhadap akuntabilitas keuangan sekolah.

Nilai R Square sebesar 0,858 atau $85,8 \%$. Angka ini menunjukkan bahwa sebesar $85,8 \%$ variabel AMKS dapat dijelaskan dengan menggunakan variabel PR, KP dan PM sedangkan sisanya $(100 \%-85,8 \%=$ $14,2 \%$ ) diterangkan oleh variabel lain yang tidak dimasukkan dalam model penelitian ini.

\section{PEMBAHASAN}

Hasil penelitian ini juga menunjukkan bahwa variabel-variabel penelitian lainnya di antaranya LP (Lingkungan Pengendalian) dan IK (Informasi dan Komunikasi) tidak berpengaruh terhadap akuntabilitas manajemen keuangan sekolah. Hal ini dapat dilihat dari nilai probabilitas signifikansi jauh di atas 0,05 . Variabel lingkungan pengendalian memiliki nilai signifikansi sebesar 0,548. Variabel informasi dan komunikasi memiliki nilai signifikansi sebesar 0,116 . Temuan di atas menyimpulkan bahwa hipotesis 1 dan hipotesis 4 ditolak. Hal ini berarti bahwa variabel lingkungan pengendalian dan informasi dan komunikasi tidak memiliki pengaruh terhadap akuntabilitas manajemen keuangan sekolah. Sari (2013) menyatakan bahwa lingkungan pengendalian merupakan unsur yang paling sulit untuk dikembangkan dan dievaluasi karena sebagian besar merupakan aspek pengendalian intern yang soft dan intangible. Lingkungan pengendalian di satuan pendidikan masih sulit untuk dicapai karena kurang tertibnya penyusunan dan penerapan kebijakan tentang pembinaan sumber daya manusia serta kurangnya komitmen terhadap kompetensi. Lemahnya lingkungan pengendalian terlihat pula pada pendelegasian wewenang dan tanggung jawab yang kurang tepat, kurangnya hubungan kerja yang baik terlihat belum terwujudnya mekanisme saling uji antar entitas/unit satuan pendidikan.

Hasil analisis penelitian ini juga menunjukkan bahwa variabel status sekolah dan ukuran sekolah sebagai variabel kontrol ternyata berpengaruh terhadap akuntabilitas manajemen keuangan sekolah. Martani dan Fazri (2011) mengemukakan bahwa pemerintah daerah yang memiliki ukuran yang lebih besar akan memiliki pengendalian intern yang lebih baik dibandingkan pemerintah daerah yang memiliki ukuran kecil. Demikian halnya dalam penelitian ini, ukuran sekolah besar yang memiliki jumlah siswa yang lebih banyak akan memiliki pengendalian yang lebih baik dibandingkan sekolah yang memiliki ukuran kecil dengan jumlah siswa yang sedikit. Sujoko dan Soebiantoro (2007) menyatakan bahwa semakin besar ukuran suatu perusahaan maka akan mempermudah perusahaan tersebut untuk memperoleh sumber pendanaan baik dari internal maupun dari eksternal. Demikian juga dalam penelitian ini ukuran sekolah besar memiliki jumlah siswa yang banyak akan memperoleh pendanaan yang lebih besar pula baik dari intern maupun dari ekstern dibandingkan ukuran sekolah kecil. Maka dapat disimpulkan bahwa sekolah yang memiliki ukuran besar akan semakin besar keuangan yang dikelola serta memiliki pengendalian intern yang lebih baik dibandingkan dengan sekolah yang memiliki ukuran kecil yang memiliki dan mengelola dana lebih sedikit.

\section{PENUTUP}

\section{Simpulan}

Berdasarkan penelitian, maka dapat ditarik suatu kesimpulan antara lain sebagai berikut.

1. Unsur lingkungan pengendalian tidak 
berpengaruh terhadap akuntabilitas manajemen keuangan sekolah.

2. Unsur penilaian risiko berpengaruh terhadap akuntabilitas manajemen keuangan sekolah.

3. Unsur kegiatan pengendalian berpengaruh terhadap akuntabilitas manajemen keuangan sekolah.

4. Unsur informasi dan komunikasi tidak berpengaruh terhadap akuntabilitas manajemen keuangan sekolah.

5. Unsur pemantauan berpengaruh terhadap akuntabilitas manajemen keuangan sekolah.

\section{Saran}

Adapun saran yang dapat diberikan kepada peneliti berikutnya berdasarkan hasil penelitian yang telah dilakukan adalah sebagai berikut.

1. Peneliti selanjutnya perlu memperluas populasi penelitian, sehingga bisa memberikan gambaran terbaru mengenai kondisi sekolah/satuan pendidikan di Jawa Timur atau bahkan di Indonesia.

2. Peneliti selanjutnya perlu mengkaji lebih dalam lagi hubungan antara status sekolah (sekolah negeri dan sekolah swasta) terhadap akuntabilitas manajemen keuangan sekolah.

3. Peneliti selanjutnya menggunakan metode penelitian kualitatif, yakni dengan mengadakan wawancara secara langsung kepada responden, sehingga diperoleh data yang lebih valid dan akurat.

\section{DAFTAR PUSTAKA}

Anggraini, R.D. 2013. Transparansi, partisipasi, dan akuntabilitas pengelolaan anggaran dana BOS dalam program RKAS di SDN Pacarkeling VIII Surabaya. Kebijakan dan Manajemen Publik FISIP, Universitas Airlangga, Vol. 1 (2): 201-208.
Badan Pengawasan Keuangan dan Pembangunan, 2010, Penilaian Risiko. Jakarta: Pusat Pendidikan dan Pelatihan Pengawasan.

Bafadal, Ibrahim. (2004). Dasar-dasar Manajemen dan Supervisi Taman Kanak-kanak. Jakarta: Bumi Aksara.

Bastian, Indra. 2007. Akuntansi Pendidikan. Bandung: Erlangga.

Boy, D. dan Siringoringo, H. 2009. Analisis pengaruh akuntabilitas dan transparansi pengelolaan anggaran pendapatan dan belanja sekolah (APBS) terhadap partisipasi orang tua murid. Jurnal Ekonomi Bisnis Universitas Gunadarma, Vol. 14 (12): 79-87.

Fadilah, S. 2011. Pengaruh implementasi pengendalian intern dan total quality management terhadap penerapan good governance (Studi pada Lembaga amil zakat seluruh Indonesia). Simposium Nasional Akuntansi XIV Aceh 2011. Artikel dipublikasikan.

Ghozali, Imam. 2009. Ekonometrika: Teori, konsep dan aplikasi dengan SPSS 17. Semarang: Badan Penerbit Universitas Diponegoro.

Istiningrum, A. 2011. Implementasi penilaian risiko dalam menunjang pencapaian tujuan instansi pendidikan. Jurnal Pendidikan Akuntansi Indonesia. Vol. 9 (2): 16-31.

Jawa Pos. 2014. Radar Madiun. Dua mantan Kasek dijerat pasal korupsi. Jum'at, 24 Oktober 2014.

Jensen, M.C. dan Meckling, W.H. 1976. Theory of the firm: Managerial behaviour, agency cost and ownership structur. Journal of Financial Economics, Vol. 3 (4): 305-360.

Kementerian Pendidikan dan Kebudayaan. 2012. Pedoman Teknis Penyelenggaraan SPIP di Lingkungan Kemendikbud. 
Kresiadanti, A.R.R. 2012. Pengaruh internal control dan internal auditor terhadap akuntabilitas di Universitas Brawijaya. (Studi pada Fakultas dan Program di Universitas Brawijaya yang telah diaudit oleh Satuan Pengendalian Internal Universitas Brawijaya tahun 2012). Tesis Pascasarjana. Fakultas Ekonomi dan Bisnis Universitas Brawijaya. Malang.

Mardiasmo. 2002. Akuntansi Sektor Publik. Yogyakarta: Penerbit Andi. -. 2006. Perwujudan Transparansi dan Akuntabilitas Publik Melalui Akuntansi Sektor Publik: Suatu Sarana Good Governance. Yogyakarta: UGM.

Martani, D. dan Fazri Z. 2011. Pengaruh ukuran, pertumbuhan, dan kompleksitas terhadap pengendalian intern pemerintah daerah. Studi kasus di Indonesia. Simposium Nasional Akuntansi XIV Aceh.

Mohamad, Ismail. 2004. Sistem akuntabilitas kinerja instansi pemerintah. Edisi kedua. diakses 23 Desember 2014 dari http:www.lan.go.id

Mulyasa. 2003. Manajemen berbasis sekolah. Konsep, strategi dan implementasi. Bandung: PT. Remaja Rosdakarya Offset.

Mustafa, I. B. 2004. Pengendalian intern dan pemberantasan korupsi. Warta Pengawasan. Vol. 9(1): 6-10.

Peraturan Menteri Pendidikan Nasional Republik Indonesia Nomor. 19 Tahun 2007 tentang standar pengelolaan pendidikan oleh satuan pendidikan dasardan menengah.

Peraturan Pemerintah Nomor 60 Tahun 2008 tentang sistem pengendalian intern pemerintah (SPIP).
Pratolo, S. 2007. Good corporate governance dan kinerja BUMN di Indonesia: Aspek audit manajemen dan pengendalian intern sebagai variabel eksogen serta tinjauannya pada jenis perusahaan. Simposium Nasional Akuntansi $X$ Makasar.

Sari, Diana. 2013. Pengaruh sistem pengendalian intern pemerintah, implementasi standar akuntansi pemerintahan, penyelesaian temuan audit terhadap penerapan prinsip-prinsip tata kelola pemerintahan yang baik (Penelitian pada pemerintah daerah di Provinsi Jawa Barat dan Banten). Simposium Nasional Akuntansi XVIManado.

Sekaran, Uma dan Bougie, R. 2009. Research methods for business: A skill building approach. Fifth Edition. New York: John Wiley \& Sons, Inc.

Sugiyono. 2012. Statistik untuk penelitian. Bandung: CV. Alfabeta.

Slamet, P.H. 2006. Manajemen berbasis sekolah: Partisipasi, transparansi, akuntabilitas, dan income generating activity. Buletin Pelangi Pendidikan, V: 4-6.

Sujoko dan Soebiantoro, Ugy. 2007. Pengaruh struktur kepemilikan saham, leverage, faktor intern dan faktor ekstern terhadap nilai perusahaan: Studi empirik pada perusahaan manufaktur dan non manufaktur di Bursa Efek Jakarta. Jurnal manajemen dan kewirausahaan. Vol. 9(1): 41-48.

Teketel, T. dan Berhanu, Z. 2009. Internal control in Swedish small and medium size enterprises. Master Thesis. Umeå School of Business - USBE. Masters in Business Administration.

Undang-Undang Republik Indonesia Nomor 20 Tahun 2003 tentang sistem pendidikan nasional. Jakarta: CV. Tamita Utama. 
Undang-Undang Republik Indonesia Nomor 1 Tahun 2004 tentang perbendaharaan negara.

Widyaningsih, A., Triantoro, A. dan Wiyantoro, L.L. 2011. Hubungan efektifitas sistem akuntansi keuangan daerah dan pengendalian intern dengan kualitas akuntabilitas keuangan: Kualitas informasi laporan keuangan sebagai variabel intervening (Penelitian pada laporan realisasi anggaran di Pemda Kabupaten/Kota wilayah Provinsi Jawa Barat). Simposium Nasional Akuntansi XIV Aceh.

Wijaya, D. 2009. Implikasi manajemen keuangan sekolah terhadap kualitas pendidikan. Jurnal Pendidikan Penabur, 13: 80-96.
Wijaya, Tony. 2012. Cepat menguasai SPSS 19 untuk olah data dan interpretasi data. Jakarta: Cahaya Atma Pustaka.

Wilopo. 2006. Analisis faktor-faktor yang berpengaruh terhadap kecenderungan kecurangan akuntansi: Studi pada perusahaan publik dan BUMN di Indonesia. Simposium Nasional Akuntansi IXPadang.

Zhumei-Li, Hongwei-He, dan Yanli-Ma. 2013. Effectiveness of internal control in China-based on panel data from listed manufacturing companies in China. Journal of Applied Sciences Vol. 13(17): 3435-3438. 